Jan Mikinka

UNIWERSYTET ŁÓDZKI

\title{
Moc dźwięku - czemu ucho przeraża nas bardziej niż oko?
}

Współczesna kultura jest zdominowana przez obraz. Warstwa wizualna zdecydowanie przeważa nad pozostałymi wrażeniami zmysłowymi. Słusznie stwierdza zatem Marcus Banks, piszac o uprzywilejowaniu „[...] wzroku kosztem innych zmysłów we współczesnych społeczeństwach Zachodu (a także w coraz większym stopniu w innych społeczeństwach)"1. Oczywiście zgadzam się ze spostrzeżeniami Banksa, jednak uważam, że owo zachłyśnięcie się wizualnościa, obrazami, ciagłym drażnieniem oka sprawiło, że coraz częściej nie doceniamy, a może nawet nie dostrzegamy równie istotniej warstwy audialnej. Moim zdaniem to właśnie ta warstwa sprawia, że film robi na nas tak duże wrażenie, potrafi wzbudzić prawdziwe emocje, a nawet strach czy panikę. Prawdziwa siłę oddziaływania dźwięku na widzów pokazują filmy grozy - horrory.

Dźwięk ma bardzo specyficzną naturę, nie możemy go zobaczyć, dotknąć, natomiast w czasie swojego trwania potrafi wypełnić całą otaczająca nas przestrzeń lub przywołać dawno zapomniane wspomnienia. W przypadku wielu dzieł filmowych to właśnie dźwięk sprawia, że obraz nabiera nastroju, wprowadza nas w pewien konkretny klimat, wzbudza uczucia. Sprawia, że widz emocjonalnie angażuje się w odbiór dzieła, niemal wchodzi do świata akcji.

Specyficzna natura dźwięku doprowadza do tego, że wpływ, jaki wywiera on na mnie samego jako widza, nie jest uświadamiany. Dźwięk jest dla odbiorcy czymś nierozerwalnie związanym $z$ obrazem - wprost $z$ niego wynikającym. Dźwięki zostają zatem zepchnięte na drugi plan, postrzega się je jako coś wtórnego względem s. 39.

1 M. Banks, Materiały wizualne w badaniach jakościowych, Warszawa 2009, 
obrazu - jeżeli widzimy, że krzesło na ekranie zostaje przesunięte, to wydobyty w ten sposób dźwięk musi wynikać $z$ owego przesunięcia. Dźwięk zawsze musi mieć swoje źródło. Nie możemy go zatrzymać ani uchwycić, jest bowiem czymś eterycznym, niewidzialnym, wręcz niematerialnym, nieposiadajacym swojej formy. Problemy z dźwiękiem spostrzega również Ong, gdy pisze:

\begin{abstract}
Wszelkie doznania rozgrywają się w czasie, dźwięk ma jednak szczególny zwiazek z czasem, różny od pozostałych odmian zmysłowych człowieka. Nie tylko po prostu znika; jest efemeryczny i tak go odbieramy. Kiedy wypowiadam słowo „trwałość”, to dochodząc do „łość”, straciłem już „trwa”. Musiałem je stracić.

Nie ma sposobu zatrzymania dźwięku, posiadania dźwięku. Mogę zatrzymać pracę kamery filmowej i pokazywać na ekranie jedno ujęcie. Zatrzymując ruch dźwięku, nie mam niczego - żadnego dźwięku, jedynie ciszę. I choć wszystkie doznania zmysłowe rozgrywaja się w czasie, to żadne inne nie jest aż tak oporne wobec działań zatrzymujących, stabilizujących. Widzenie pozwala zarejestrować ruch, może jednak rejestrować również bezruch. Więcej nawet, widzenie preferuje bezruch, oglądając bowiem coś dokładnie, wolimy, by pozostawało nieruchome. Często sprowadzamy ruch do serii kolejnych ujęć, by lepiej zobaczyć, czym jest ruch. Nie istnieje odpowiednik „serii ujęć” dla dźwięku. Oscylogram jest cichy. Tkwi poza światem dźwięku².
\end{abstract}

$Z$ racji wspomnianej ulotności analiza dźwięków jest niezwykle trudna. W badaniach nad filmem wypracowano kilka podziałów warstwy audialnej, towarzyszaccej obrazowi. Najbardziej podstawowy z nich wyróżnia trzy rodzaje dźwięków - mowę, muzykę i odgłosy (efekty dźwiękowe). Często jednak dźwięki przekraczaja te kategorie; innymi słowy - nie zawsze jesteśmy w stanie stwierdzić, czy dany dźwięk przynależy wyłącznie do jednej $z$ wymienionych grup.

Problemów $z$ kategoryzowaniem nie udało się również rozwiązać, wprowadzając inny podział dźwięków: na niediegetyczne, pochodzace spoza świata przedstawionego (do nich należałaby np. muzyka ilustracyjna) oraz diegetyczne, czyli te, które maja swoje źródło w świecie przedstawionym (np. rozmowy bohaterów, dźwięki ich kroków itd.). Ponadto dźwięki diegetyczne moga być zewnętrzne, ich źródło widzimy na obrazie, bądź wewnętrzne, których przykładem sa wypowiadane $z$ offu (czyli spoza kadru) myśli bohatera, gdy ten w danym momencie nie porusza na ekranie swo-

${ }^{2}$ W. Ong, Psychodynamika oralności, tłum. J. Japola, [w:] Antropologia słowa. Zagadnienia i wybór tekstów, red. G. Godlewski, A. Mencwel, R. Sulima, Warszawa 2003, s. 191. 
imi ustami. Dźwięki niediegetyczne i diegetyczne wewnętrzne określa się wspólnym mianem sound over, ponieważ nie pochodzą one $z$ realnej przestrzeni sceny ${ }^{3}$.

W horrorach często trudno jest odróżnić dźwięki diegetyczne od niediegetycznych, jednak w większości filmów tego typu to właśnie dźwięki niediegetyczne potrafia przyprawić nas o palpitacje serca. Doskonałym tego przykładem jest Psychoza Hitchcocka - słynna scena morderstwa pod prysznicem nie robi na nas prawie żadnego wrażenia bez towarzyszacych jej wysokich, niezwykle ostrych i dynamicznych dźwięków skrzypiec. To właśnie ten dźwięk jest tym, co nas przeraża - należy w tym miejscu dodać, że w całej scenie nie ma ani jednego ujęcia przedstawiającego wbicie noża w ciało ofiary; nawet znikająca w spływie krew, pozbawiona na czarno-białej kliszy swojej wyrazistej, czerwonej barwy, traci wymowność.

Kolejnym przykładem może być film Paranormal activity. W większości scen wspomnianego filmu napięcie rośnie wyłącznie wskutek wystapienia w pewnym momencie, trudnego do sklasyfikowania, specyficznego dźwięku, który ma oznaczać pojawienie się $\mathrm{w}$ pokoju nadnaturalnych sił. W filmie tym wiele ujęć przedstawia w bardzo statyczny sposób te same pomieszczenia, w których prawie nic się nie dzieje; praca kamery zredukowana jest do minimum. Dopiero wprowadzenie nowego elementu, jakim jest tajemniczy dźwięk, przełamuje tę monotonię i wzbudza niepokój.

Dzięki tym dwóm przykładom, przywodzącym na myśl zupełnie inne rodzaje dźwięków wzbudzających w nas przerażenie, możemy wyróżnić dwie kolejne cechy dźwięków wpływające na nasze pobudzenie bądź odczucie przerażenia. Pierwsza $z$ nich jest zmiana dynamiki dźwięku, inaczej - manipulowanie głośnością. Nagłe uderzenie dźwięku nie tylko nas zaskakuje, ale może wręcz boleć, gdy organizm nie będzie gotów na przyjęcie zbyt głośnego dźwięku. Druga cecha jest natomiast wysokość dźwięku - przed bardzo wysokimi dźwiękami odczuwamy naturalny lęk; wiąże się to również $z$ bólem, odczuwanym podczas słuchania fal dźwiękowych o zbyt dużej częstotliwości.

Należy w tym miejscu zaznaczyć, że człowiek w konfrontacji $z$ dźwiękiem jest stworzeniem dość bezbronnym, nie posiada bowiem żadnego naturalnego stopera. Aby przestać widzieć, obronić się przed widokiem, którego nie chcielibyśmy zobaczyć,

3 D. Bordwell, K. Thompson, Film Art. Sztuka filmowa. Wprowadzenie, tłum. B. Rosińska, Warszawa 2010. 
wystarczy zamknąc powieki, nie jesteśmy natomiast $\mathrm{w}$ stanie w równie prosty sposób przestać słyszeć. Zmysły pomagaja nam przetrwać w nieznanym środowisku, dzięki nim jesteśmy w stanie zlokalizować potencjalne niebezpieczeństwo i ustrzec się przed jego skutkami. W dużej mierze to właśnie słuchowi zawdzięczamy nasze przetrwanie, nawet współcześnie jest on narzędziem do wychwytywania alarmów - wystarczy usłyszeć dzwonek alarmu, klakson, sygnał karetki, radiowozu bądź grzmot pioruna, a od razu odczuwamy niemiłe napięcie.

Taka, a nie inna reakcja ludzkiego organizmu na dźwięki ma swoje podłoże biologiczne, jest swoistym atawizmem. Jednym $z$ mało znanych odkryć Pawłowa jest tzw. odruch orientacyjny - jak pisze Piotr Jaśkowski, jest on

[...] pierwszą odpowiedzią ciała na każdy bodziec i jego zadaniem jest dostrojenie układu nerwowego do optymalizacji odbioru informacji $z$ otoczenia. Tak więc OR jest koordynowana centralnie odpowiedzia układu autonomicznego i ruchowego. Przejawia się ona według Sokolova wzrostem przewodności skóry, rozszerzeniem źrenic, spadkiem tętna, zwężeniem naczyń krwionośnych kończyn oraz blokowaniem rytmu alfa EEG. Natomiast odpowiedź ruchowa oznacza skierowanie receptorów w stronę napływających informacji. Na przykład pojawienie się nagłego bodźca słuchowego wywołuje skierowanie głowy w stronę źródła dźwięku poprzedzone ruchem gałek ocznych ${ }^{4}$.

To właśnie dzięki temu bezwarunkowemu odruchowi oraz swoistej niemocy przed zaprzestaniem słuchania często jesteśmy wodzeni za nos, a właściwie za ucho, przez filmowców sprawnie posługujących się odpowiednim zestawieniem dźwięku i obrazu.

Sam obraz, nawet przy bardzo dynamicznej pracy kamery, nie jest w stanie wzbudzić w nas takich emocji jak obraz, któremu towarzyszą dźwięki. Bez dźwięku większość horrorów przestaje straszyć, nie potrafia „zaatakować nas” dostatecznie mocno. To właśnie dźwięk przełamuje barierę wielkiego ekranu i wchodzi w zmysłowe życie zwykłych odbiorców. Drgania fal dźwiękowych sprawiaja, że obraz zostaje przełożony na fizyczne odczucia obserwatorów - krzyki i odgłosy (zwłaszcza w przypadku horrorów) staja się głównymi aktorami. Aktorami, którzy - w tym specyficznym czasie i przestrzeni, jaka jest sala kinowa - sa w stanie nawiązać $z$ widzami bezpośredni kontakt. Niemalże dotknięty za ich pośrednictwem widz przestaje być jedynie zdystansowanym obserwatorem, przeistaczając się w uczestnika akcji, staje się niejako bohaterem

${ }^{4}$ P. Jaśkowski, Zarys psychofizjologii, Warszawa 2004, s. 162. 
przedstawianych zdarzeń. Wracając do horroru, możemy stwierdzić, że to właśnie dźwięk decyduje o tym, czy dane ujęcie nas przeraża czy nie.

Dźwięk to życie, jego brak oznacza śmierć. O słuszności tego prostego stwierdzenia możemy się przekonać na sali porodowej, niczym innym bowiem jak symbolem samego życia jest krzyk nowo narodzonego dziecka. Wydanie $z$ siebie dźwięku wymaga siły. Jak zauważa Ong, dźwięk już w czasach kultur oralnych kojarzony był $z$ siła; wynikało to $z$ konieczności podjęcia pewnego wysiłku, aby dźwięk wydobyć. To właśnie w wyniku tego skojarzenia słowa (rozumiane tu jako wypowiadane dźwięki) zyskały sprawczą i magiczną moc - przestaliśmy „wywoływać wilka z lasu”. Według Onga:

[...] słowa maja wielką moc. Dźwięk nie może rozbrzmiewać bez użycia siły. Myśliwy może przyglądać się bawołu, wąchać go, dotykać, o ile ten pozostaje całkowicie nieruchomy czy martwy, kiedy jednak słyszy bawołu, musi mieć się na baczności; bowiem coś się dzieje. W tym sensie każdy dźwięk, a zwłaszcza wypowiedź oralna, pochodząca $z$ wnętrza żywego organizmu, jest „dynamiczna”.

Fakt, że ludy uważaja zazwyczaj, a prawdopodobnie powszechnie, że słowo ma moc magiczną, wiąże się wyraźnie, choćby nieświadomie, $z$ kojarzeniem słowa $z$ mówieniem, $z$ brzmieniem, $z$ używaniem siły. [...] Słowo mówione, wydobywające się $z$ ludzkiego wnętrza, $z$ uwagi na fizyczne właściwości dźwięku objawia sobie nawzajem istoty ludzkie jako wnętrza świadome, jako osoby; to słowo mówione tworzy z poszczególnych ludzi ściśle powiązaną grupę ${ }^{5}$.

Magiczne słowa nie są więc absurdalnym wymysłem, ale wynikiem pewnego, wypracowywanego przez pokolenia, niemalże logicznego ciagu skojarzeń, którego wynik został utrwalony w kulturze pod postacia przesądów, a co za tym idzie - mocy nadawanej pewnym konkretnym słowom (przekleństwa, zauroczenia itd.). Pozostałości kultury oralnej wciąż funkcjonują w otaczajacym nas świecie.

Słowo kryje w sobie wielką moc, która wynika nie tylko $z$ jego $z$ naczenia, lecz także $z$ samej siły głosu. Ong podkreśla również, że „dla ludów "prymitywnych" (oralnych) język jest sposobem dzia-

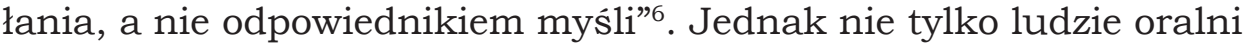
wierza, że nazwy dają im władzę nad rzeczami i są stanie wpływać na otaczająca nas rzeczywistość; w wielu współczesnych filmach również możemy dostrzec tego typu przekonanie. W większości filmów o egzorcyzmach bohater nie jest w stanie wygnać demona,

\footnotetext{
5 W. Ong, dz. cyt., s. 192.

6 Tamże.
} 
dopóki nie pozna jego imienia, to właśnie imię sprawia, że demon się podporządkowuje, musi ulec woli egzorcysty, posłuchać go. Doskonałym przykładem takiego myślenia jest finałowa scena w filmie Rytuał Mikaela Håfströma, w której główny bohater nie może poradzić sobie $z$ demonem do czasu poznania jego imienia. Gdy demon wyjawia w końcu swoje imię, egzorcyzm zostaje dopełniony.

Dźwięk w filmie to niezwykle obszerny temat, moim zdaniem wciąż mało zbadany i wiele kryjący. Dźwięk w filmie - czego, mam nadzieję, udało mi się dać niewielki przykład - można badać pod wieloma kątami i $z$ różnych perspektyw, np. wpływu na widza, postprodukcji, kompozycji, a nawet bohatera akcji filmu. Myślę, że każda $z$ nich może dać zupełnie inne i niespodziewane rezultaty. Wcią̇ odnoszę wrażenie, że pomimo tak dużego znaczenia, jakie pełnią dźwięki w otaczającym nas świecie, wciąż nie poświęca się im dostatecznie dużo uwagi. Poważne badania tego tematu mogłyby mieć wymiar niezwykle szeroki i interdyscyplinarny, ponieważ problematyka związana $z$ dźwiękiem i reakcjami przez niego wywoływanymi leży w polu zainteresowań wielu dyscyplin.

\section{Bibliografia}

Bordwell D., Thompson K., Film Art. Sztuka filmowa. Wprowadzenie, tłum. B. Rosinska, Warszawa 2010.

Jaśkowski P., Zarys psychofizjologii, Warszawa 2004.

Ong W., Psychodynamika oralności, tłum. J. Japola, [w:] Antropologia słowa. Zagadnienia i wybór tekstów, red. G. Godlewski, A. Mencwel, R. Sulima, Warszawa 2003, s. 191-202.

\section{Filmografia}

Ostatni egzorcyzm 2, reż. E. Gass-Donnelly, 2013.

Paranormal activity, reż. O. Peli, 2007.

Psychoza, reż. A. Hitchcock, 1960.

Rytuał, reż. M. Håfström, 2011.

\section{Abstract}

The extraction of sound is associated with a certain effort of the force, therefore - according to the beliefs of many cultures - sounds have magic power and they are able to influence reality that surround us. Sounds evoke memories; can present non-physical force, engaging us into situations which they relate to. Human does not have any effective filters that can protect him from sounds. Modern 
cinema has been subordinated to the dictates of the "eye". Movies daze our sense of the sight. Although we cannot forget that the film projections (even silent ones) always have been accompanied by sounds. Video without sound will not make such impression on a viewer, like a movie with sound. The sound creates a profundity, introduces us to a particular mood, it is even able to temporarily blur the line between a cinema screen and a recipient - between reality and fiction. Trough auditory stimuli spectator ceases to be a passive observer, he is immersed into the film action - he becomes its participant, he begins to experience authentic emotion, a horror movie frightens us because it becomes authentic.

Key words: a modern horror, a film sound, an aural and oral culture, anthropology of the senses. 